\title{
Deepening Ukraine-Poland economic integration through investment cooperation
}

\author{
Myron Yankiv \\ General Consul of Ukraine in Gdansk, Poland \\ kgu@kgu.internetdsl.pl \\ Mariia Yankiv \\ Institute of International Relations \\ Taras Shevchenko National University of Kyiv, Ukraine \\ marya.yankiv@gmail.com
}

Abstract. The aim of the study is to analyze the amount of foreign direct investment in-

Received:

December, 2012

1st Revision:

March, 2013

Accepted:

May, 2013 Ukraine, because they believe that the Ukrainian market is attractive to them against the backdrop of the problems that are currently going within the EU countries. In particular, the investment attractiveness of Ukraine is proved by its advantageous geographic location, large domestic consumer market, skilled labor force.

Keywords: foreign direct investment, economic integration, Poland, Ukraine

JEL classification: E2, F15, P2

\section{INTRODUCTION}

The analysis of export-import trade flows between Ukraine and Poland compels paying primary attention to the causes that for a long time give rise to the existence of some constraints and restrictive barriers in the Polish-Ukrainian trade. As already noted, these reasons have both objective and subjective sources of their own creation, and their negative effect applies not only onto bilateral trade cooperation between Ukraine and Poland, but also appears in the sphere of investment cooperation between the two countries. As a result, most of the above problems and structural imbalances highlighted by the example of UkrainianPolish trade in goods and services are reflected in the investment dimension.

This primarily refers to the discrepancy between the total amount of FDI invested by Polish entrepreneurs into the Ukrainian economy and Ukrainian - into Polish, as well as sectorial and structural heterogeneity of the flow appropriate investment of resources between Ukraine and Poland.

Thus, analyzing the amount of foreign direct investments invested in the Ukrainian economy by Polish businessmen after Poland's accession to the EU in comparison with those investments that were made in the 
same period from Ukraine to Poland, prior attention is drawn to the wide variations of these parameters as a whole, and within individual years in particular (Table 1).

Table 1

Amounts of foreign direct investments borrowed and invested between Ukraine and Poland (mln US dollars)

\begin{tabular}{|c|c|c|c|c|c|c|}
\hline \multirow{2}{*}{ Index } & \multicolumn{6}{|c|}{ Years } \\
\hline & 2005 & 2006 & 2007 & 2008 & 2009 & 2010 \\
\hline \multicolumn{7}{|c|}{ Total amount of attracted foreign direct investments into Ukraine } \\
\hline Total & 16890,0 & 21607,3 & 29542,7 & 35616,4 & 40053,0 & 44708,0 \\
\hline Within a year & 7843,0 & 4717,3 & 7935,4 & 6073,7 & 4436,6 & 4655,0 \\
\hline$\%$ & 46,4 & 21,8 & 26,9 & 17,1 & 11,1 & 10,4 \\
\hline \multicolumn{7}{|c|}{ Amount of attracted foreign direct investments into Ukraine from Poland } \\
\hline Total & 225,5 & 394,6 & 672,1 & 690,1 & 866,7 & 935,8 \\
\hline Within a year & 30,8 & 169,1 & 277,5 & 18,0 & 176,6 & 69,1 \\
\hline$\%$ & 15,8 & 75,0 & 70,3 & 2,7 & 25,6 & 7,9 \\
\hline \multicolumn{7}{|c|}{ Total amount of exported foreign direct investments from Ukraine } \\
\hline Total & 219,5 & 243,3 & 6196,6 & 6203,1 & 6226,3 & 6871,1 \\
\hline Within a year & 20,9 & 23,8 & 5953,3 & 6,5 & 29,7 & 644,8 \\
\hline$\%$ & 10,5 & 10,8 & 24,5 рази & 0,1 & 0,5 & 10,4 \\
\hline \multicolumn{7}{|c|}{ Total amount of exported foreign direct investments from Ukraine to Poland } \\
\hline Total & 21,3 & 24,2 & 30,1 & 46,9 & 49,4 & 49,1 \\
\hline Within a year & 0,2 & 2,9 & 5,9 & 16,8 & 2,5 & $-0,3$ \\
\hline$\%$ & 1,0 & 13,6 & 24,3 & 55,8 & 5,3 & $-0,6$ \\
\hline
\end{tabular}

Source: State Committee of Statistics and Ministry of economy of Ukraine.

On average during 2005-2010 the total amount of FDI involved into Ukraine from Poland exceeded the same amount of export of Ukrainian investments into the Polish economy by 16 times. Thus in some periods (2007) this ratio amounted to 22.3 times, and as of January 1, 2011 was more than 19 times. However, in general, the said ratio for Ukraine during 2007-2010 ranged between $4.8-6.5$ times, and as at the beginning of 2011 there was three times inferior disparities between involved and invested foreign direct investments between Ukraine and Poland. In addition, in 2010 there was extracting Ukrainian equity of Poland against 69.9 million of invested FDI from Poland to Ukraine. This suggests that in fact, in 2010 the ratio between the annual volume of attracted foreign direct investment from Poland to Ukraine and volume of investment resources invested in return by domestic entrepreneurs into Poland was more than 70 times, while the total annual figures for exports and imports of foreign direct investment into Ukraine with all countries during 2010, this ration was only 7.2 times.

The situation is complicated by the fact that foreign direct investments into Ukraine from Poland are greatly less than those within the investment cooperation between Ukraine and other countries of the world. Thus, the share of Polish foreign direct investments in the total amount of foreign direct investments to Ukraine during the years of 2004-2010 ranged from $1.3 \%$ to $2.3 \%$ and the volume of foreign direct investment during one year did not exceed $4.0 \%$, on average accounting for $2.2 \%$.

It should be noted that share of Poland in FDI exports comparing to other countries in the world are much more significant. Thus, from 2004 to 2010, this figure does not fall below 8\% (if Ukrainian investments in Cyprus are excluded from the calculation, as they cannot be considered as direct investment, but as 
a means of optimizing the business tax), and for the last three years was of average almost $11 \%$. As regarded the annual FDI from Ukraine to Poland there is a significant level of differentiation indices for individual years, as well as for investment in other states and abroad in general. This indicates a lack of power and consistency of local business, but would also demonstrate a significant level of attractiveness of the Polish market for Ukrainian capital, despite the fact that in 2010 it was de-investment from Poland at the amount of 0.3 million US dollars.

Note that just as in trade of goods and services in the Ukrainian-Polish investment cooperation there is a gap between the observed volume of investment flows and calculated values of potential investments from Poland to Ukraine, obtained by applying the gravity model (Table 2). Unfortunately, it was not possible to analyze compliance force of economic gravity of foreign direct investment from Ukraine to Poland and other neighboring countries due to the lack of actual statistics and sharp fluctuations of indicators, but in general we can say that they have identified the parameters closer to the estimated level than in the case of attracted foreign direct investment into Ukraine.

Table 2

Comliance of the amount of economic gravity force Invested into Ukrainian economy from the neighboring countries (as of 1.01.2011, mln US dollars)

\begin{tabular}{|l|c|c|c|c|}
\hline \multicolumn{1}{|c|}{ Country } & $\begin{array}{c}\text { Gravity } \\
\text { force, } \%\end{array}$ & $\begin{array}{c}\text { Actual amount of attracted } \\
\text { investment }\end{array}$ & $\begin{array}{c}\text { Estimated } \\
\text { investment }\end{array}$ & $\begin{array}{c}\text { Underinvestment } \\
\text { (over-investment) }\end{array}$ \\
\hline Poland & 21,65 & 935,8 & 1129,5 & $-193,7(20,7 \%)$ \\
\hline Russia & 55,90 & 3402,8 & 2916,4 & $+486,4(16,7 \%)$ \\
\hline Belarus & 9,93 & 43,7 & 518,1 & $-474,4(11$ times $)$ \\
\hline Hungary & 3,34 & 723,6 & 174,3 & $+549,3(3$ times $)$ \\
\hline Romania & 6,52 & 21,0 & 340,2 & $-319,2(15$ times $)$ \\
\hline Slovak Republic & 1,71 & 62,7 & 89,2 & $-26,5(42,3 \%)$ \\
\hline Moldova & 0,95 & 27,7 & 49,6 & $-21,9(79,1 \%)$ \\
\hline Total & $\mathbf{1 0 0 , 0 0}$ & $\mathbf{5 2 1 7 , 3}$ & $\mathbf{5 2 1 7 , 3}$ & $\mathbf{0 , 0}$ \\
\hline
\end{tabular}

Source: State Committee of Statistics and Ministry of economy of Ukraine ${ }^{1}$

As can be seen from the data, Poland, along with Belarus, Romania, Slovakia and Moldova is one of those neighboring Ukraine states that have not fully use the available power of the mutual gravitational attraction of economies in terms of foreign direct investment into the economic complex of the country. However, foreign direct investment into Ukraine from Russia and Hungary dominated over the estimated parameters obtained on the basis of using gravity model.

At the same time, it should be noted that underinvestment into the Ukrainian economy from Poland is the least significant of all the above-mentioned countries, especially in comparison with Romania and Belarus. However, over the past two years the amount of the specified underinvestment increased almost by 5 times in absolute terms (from 41.4 to 193.7 million of U.S. dollars) or $14.7 \%$ as a percentage (from $6.0 \%$ to $20,7 \%$ ), or 179 million of U.S. dollars, or $11 \%$ compared to $2004^{2}$.

1 Sources: www.ukrstat.gov.ua; http://www.ukrexport.gov.ua

2 Calculated according to: Borshchevskyy V. Ukraine and Poland under the conditions of enlarged EU: economic optimization and global partnership (Борщевський В. Україна і Польща в умовах розширеного ЄС: економічна оптимізація та глобальне партнерство). - Львів : Аверс, 2009. - С.82. 
The share of Polish investment into Ukraine does not look the best way, especially comparing to the developed countries and neighboring EU countries. Thus, if taking as a unit the rates to Germany, the design parameters of the investment from Poland to Ukraine and the other way, obtained on the basis of gravity model show that underinvestment from Poland as of 1 January 2011 was 4371.9 million of US dollars, or 4.7 times less than potential output based on the coefficient of the gravitational attraction of Ukrainian and Polish economies. This gap is comparable with those of Slovakia (5.8 times) and is behind Russia (three times), and significantly ahead of Romania (76.5 times). However, for Hungary, the UK and the U.S.A the figures of invested into Ukraine FDI exceed the estimates of investment by 20-30\% (Table 3)

Table 3

Complience of Investment Into Ukraine and from Ukraine with the Economic gravity force with some countries (as of 1.01.2011, mln US dollars)

\begin{tabular}{|c|c|c|c|c|c|}
\hline \multirow[t]{2}{*}{ Country } & \multirow[t]{2}{*}{$\begin{array}{l}\text { Ratio of gravita- } \\
\text { tional attraction }\end{array}$} & \multicolumn{2}{|c|}{$\begin{array}{l}\text { Attracted investment } \\
\text { mln US dollars }\end{array}$} & \multicolumn{2}{|c|}{$\begin{array}{c}\text { Invested } \\
\text { mln US dollars }\end{array}$} \\
\hline & & In fact & Potentially & In fact & Potentially \\
\hline Germany & 1,00 & 7076,9 & 7076,9 & 9,2 & 9,2 \\
\hline Poland & 0,75 & 935,8 & 5307,7 & 49,1 & 6,9 \\
\hline Underinvestment & & \multicolumn{2}{|c|}{4371,9 (4,7 times) } & \multicolumn{2}{|c|}{-} \\
\hline Excess investment & & \multicolumn{2}{|c|}{-} & \multicolumn{2}{|c|}{42,2 (6,1 times) } \\
\hline Russia & 1,94 & 3402,8 & 13729,2 & 194,3 & 17,8 \\
\hline Underinvestment & & \multicolumn{2}{|c|}{10326,4 (3 times) } & \multicolumn{2}{|c|}{-} \\
\hline Excess investment & & \multicolumn{2}{|c|}{-} & \multicolumn{2}{|c|}{176,5 (9,9 times) } \\
\hline USA & 0,13 & 1192,4 & 920,0 & - & - \\
\hline Underinvestment & & \multicolumn{2}{|c|}{-} & \multicolumn{2}{|c|}{-} \\
\hline Excess investment & & \multicolumn{2}{|c|}{$272,4(29,6 \%)$} & & \\
\hline Great Britain & 0,24 & 2298,8 & 1698,5 & - & - \\
\hline Underinvestment & & \multicolumn{2}{|c|}{-} & \multicolumn{2}{|c|}{-} \\
\hline Excess investment & & \multicolumn{2}{|c|}{$600,3(35,3 \%)$} & \multicolumn{2}{|c|}{-} \\
\hline Hungary & 0,12 & 723,6 & 849,2 & - & - \\
\hline Underinvestment & & \multicolumn{2}{|c|}{-} & \multicolumn{2}{|c|}{-} \\
\hline Excess investment & & \multicolumn{2}{|c|}{$126,5(17,4 \%)$} & \multicolumn{2}{|c|}{-} \\
\hline Romania & 0,23 & 21,0 & 1627,7 & - & - \\
\hline Underinvestment & & \multicolumn{2}{|c|}{1606,7 (76,5 times) } & \multicolumn{2}{|c|}{-} \\
\hline Excess investment & & \multicolumn{2}{|c|}{-} & \multicolumn{2}{|c|}{-} \\
\hline Slovak Republic & 0,06 & 62,7 & 424,6 & - & - \\
\hline Underinvestment & & \multicolumn{2}{|c|}{361,9 (5,8 times) } & \multicolumn{2}{|c|}{-} \\
\hline Excess investment & & \multicolumn{2}{|c|}{-} & \multicolumn{2}{|c|}{-} \\
\hline
\end{tabular}

Source: State Committee of Statistics and Ministry of economy of Ukraine.

Analyzing the industrial structure of Polish direct investment into Ukraine, attention is drawn to the fact of significant predominance of investments in the financial sector, in which, as at the beginning of 2011, there is concentrated more than half of the capital invested from Poland to Ukraine. Moreover, since 2006 there has been steady an increase in the share of the financial sector in the total investment (Table 3.11). The most crucial Polish investors in this segment of the market are banks: Pekao SA (invested into UniCredit 
Ukraine), PKO BP SA (investment into Kredobank), GetinHolding (invested into "Plus Bank"), as well as insurance group PZU (investment into the company "PZU Ukraine").

Foreign direct investments from Poland into the Ukrainian industry are just over $25 \%$ of total investment, and their share has a strong downward trend during the years of 2005-2010. This is especially true for the chemical and wood processing industry, whose share in the amount of foreign direct investment from Poland into Ukraine during 2006 - 2011 decreased by $14.0 \%$ and 10.6\%, respectively (Table 4).

Table 4

Foreign direct investments from poland into ukrainian economy Ukraine by types of economic activity ${ }^{1}$ as of the beginning of the year, $\%$

\begin{tabular}{|c|c|c|c|c|c|c|c|c|}
\hline & 2002 & 2005 & 2006 & 2007 & 2008 & 2009 & 2010 & 2011 \\
\hline 1 & 2 & 3 & 4 & 5 & 6 & 7 & 8 & 9 \\
\hline Poland, mln US dollars & 69,3 & 194,7 & 225,5 & 394,6 & 672,1 & 690,1 & 866,7 & 935,8 \\
\hline Total, $\%$ & 100,0 & 100,0 & 100,0 & 100,0 & 100,0 & 100,0 & 100,0 & 100,0 \\
\hline Financial activity & 32,8 & 22,9 & 20,2 & 39,2 & 51,1 & 50,4 & 56,5 & 56,9 \\
\hline Industry & 39,5 & 57,4 & 58,7 & 43,2 & 30,6 & 31,0 & 25,9 & 25,1 \\
\hline \multicolumn{9}{|l|}{ Including } \\
\hline Processing & 39,4 & 57,3 & 57,8 & 42,4 & 30,1 & 30,2 & 25,3 & 24,6 \\
\hline \multicolumn{9}{|l|}{ Including } \\
\hline $\begin{array}{l}\text { metallurgy manufacture and manufac- } \\
\text { ture of fabricated metal products }\end{array}$ & 8,8 & 4,1 & 4,3 & 12,3 & 8,9 & 10,2 & 8,4 & 7,4 \\
\hline other industries & 5,1 & 10,8 & 12,9 & 10,0 & 7,9 & 8,4 & 7,9 & 7,3 \\
\hline chemical and petrochemical industry & 3,6 & 17,1 & 17,3 & 4,5 & 3,0 & 4,0 & 3,3 & 3,3 \\
\hline $\begin{array}{l}\text { food, beverages and tobacco products } \\
\text { manufacture }\end{array}$ & 8,4 & 2,9 & 3,4 & 2,1 & 1,9 & 3,3 & 2,1 & 2,4 \\
\hline light industry & 4,2 & 2,6 & 2,4 & 2,7 & 1,1 & 1,2 & 1,0 & 1,2 \\
\hline $\begin{array}{l}\text { manufacture of other non-metallic min- } \\
\text { eral products }\end{array}$ & 2,3 & 2,0 & 2,3 & 1,7 & 0,8 & 0,9 & 0,9 & 0,8 \\
\hline $\begin{array}{l}\text { processing of timber and wood prod- } \\
\text { ucts, except furniture }\end{array}$ & 3,5 & 14,2 & 11,6 & 7,1 & 5,2 & 0,8 & 0,6 & 1,0 \\
\hline $\begin{array}{l}\text { pulp and paper industry and publishing } \\
\text { activities }\end{array}$ & 0,3 & 1,4 & 1,6 & 0,9 & 0,6 & 0,6 & 0,5 & 0,6 \\
\hline machine engineering & 3,5 & 2,3 & 2,2 & 1,2 & 0,8 & 0,8 & 0,5 & 0,5 \\
\hline mining & 0,1 & 0,2 & 0,9 & 0,8 & 0,5 & 0,7 & 0,6 & 0,5 \\
\hline $\begin{array}{l}\text { Real estate, renting and service to busi- } \\
\text { ness activities }\end{array}$ & 1,9 & 4,6 & 6,8 & 7,1 & 5,3 & 6,1 & 5,4 & 7,6 \\
\hline $\begin{array}{l}\text { Trade; repair of motor vehicles, house- } \\
\text { hold goods and personal use }\end{array}$ & 20,3 & 11,2 & 9,8 & 7,3 & 6,3 & 5,6 & 5,9 & 4,8 \\
\hline Agriculture, hunting, forestry & 1,0 & 0,8 & 0,9 & 0,8 & 4,0 & 4,7 & 3,4 & 3,1 \\
\hline Construction & 1,3 & 0,8 & 1,1 & 1,2 & 1,4 & 1,1 & 1,5 & 1,4 \\
\hline Transport and communication activity & 1,0 & 1,1 & 1,1 & 0,7 & 1,0 & 0,9 & 1,1 & 1,0 \\
\hline
\end{tabular}

${ }^{1}$ List of economic activities is defined on the basis of the largest investments made into the economy of Ukraine.

Source: State Committee of Statistics and Ministry of economy of Ukraine. 
The most crucial Polish investments into Ukrainian industry is a factory of building ceramics "Cersanit", flooring factory "Barlinek", Furniture Factory "New Style”, packaging factory "Ken-Pack", plant of car parts "Inter-Hroklin", factory meat "PKM Duda". ${ }^{3}$

It should be noted that after Poland's accession to the EU (during 2005-2010), the annual Polish structure of direct investment into Ukrainian economy had high volatility, both in industry and in the time dimension. Thus, the share of direct investment in the financial sector ranged from 3.2\% (in 2005) to 80.4\% (in 2009), the share of investment in real estate, leasing, renting and business activities during 2007-2010 years was changing from year to year by $30 \%$, in turn increasing, and then decreasing. A similar situation was observed in investing from Poland into the trade (car repairs, household goods and personal use): in 2008 and 2010 there was observed a significant withdrawal of investment. Divestment in the last two years also takes place in agriculture.

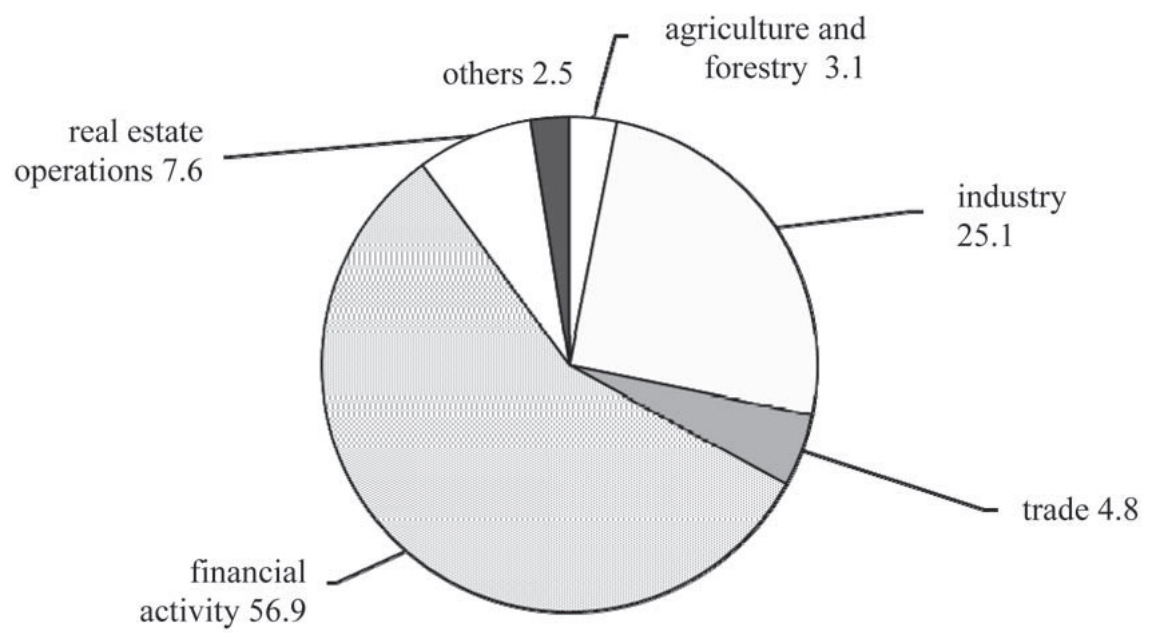

Figure 1. Structure of Foreign Direct Investment into Ukraine from Poland by economic activity, as of $01.01 .2011, \%$

The nature of investment cooperation between Ukraine and Poland in separate regions and regions of our country, confirms the high level of uneven geographical distribution of the Polish capital invested into the Ukrainian economy.

Just as in the export and import of goods and services, the lion's share of FDI from Poland to Ukraine is concentrated in the western regions. Kyiv and Kyiv region has also a high share. In general, these regions account for almost $75 \%$ of Polish direct investment in Ukrainian economy. At the same time, in the total foreign direct investment into Ukraine, most of the regions that are leaders in the Ukrainian-Polish co-investment do not show much success.

Thus, the share of Lviv and Volyn regions, which have attracted more than $50 \%$ of direct investments from Poland, in terms of all-Ukrainian amount of FDI form all countries accounts for less than 5\%, and the share of Lviv, Volyn, Ivano-Frankivsk, Vinnytsya oblasts (regions) in economic complexes of which Polish

\footnotetext{
3 Investment cooperation between Ukraine and the Republic of Poland (2010) [Internet resource]. - http://www.ukrexport.
} gov.ua/ukr/inf_spiv/pol/5119.html 
investments play a special role (making up from $14.5 \%$ to $46.1 \%$ of total FDI into the region, or an average of more than $25 \%$ of the index) with the average foreign direct investment at $1,35 \%$ in all-Ukrainian scale (Table 5)

Table 5

Foreign direct investment into Ukrainian regions from all of the world countries and from Poland as of 01.01 .2011

\begin{tabular}{|c|c|c|c|c|c|}
\hline \multirow{2}{*}{ Region } & \multicolumn{2}{|c|}{$\begin{array}{c}\text { Attracted investments, mln US } \\
\text { dollars }\end{array}$} & \multirow{2}{*}{$\begin{array}{l}\text { Share of Poland in } \\
\text { the region's invest- } \\
\text { ment, \% }\end{array}$} & \multicolumn{2}{|c|}{$\begin{array}{l}\text { Share of the region in the invest- } \\
\text { ments attracted into Ukraine, \% }\end{array}$} \\
\hline & Total & Including Poland & & Total & From Poland \\
\hline Lviv & 1273,8 & 339,9 & 26,7 & 2,9 & 35,7 \\
\hline Volyn & 344,1 & 158,7 & 46,1 & 0,8 & 17,0 \\
\hline City of Kyiv & 21859,2 & 122,9 & 0,6 & 48,9 & 13,1 \\
\hline Kyiv & 1603,0 & 82,8 & 5,2 & 3,6 & 8,8 \\
\hline Ivano-Frankivsk & 542,6 & 81,7 & 15,1 & 1,2 & 8,7 \\
\hline Kharkiv & 2705,4 & 34,0 & 1,3 & 6,1 & 3,6 \\
\hline Zakarpattya & 362,6 & 32,6 & 9,0 & 0,8 & 3,5 \\
\hline Vinnytsya & 212,5 & 30,9 & 14,5 & 0,5 & 3,3 \\
\hline Zhytomyr & 277,0 & 10,9 & 3,9 & 0,6 & 1,2 \\
\hline Khmelnytsk & 183,5 & 7,2 & 3,9 & 0,4 & 0,8 \\
\hline Ternopil & 65,1 & 5,6 & 8,6 & 0,2 & 0,6 \\
\hline $\begin{array}{l}\text { Together in the men- } \\
\text { tioned regions }\end{array}$ & 29230,8 & 907,2 & 3,1 & 65,4 & 96,9 \\
\hline Ukraine, total & 44708,0 & 935,8 & 2,1 & 100,0 & 100,0 \\
\hline
\end{tabular}

Source: State Committee of Statistics and Ministry of economy of Ukraine.

This means that the Polish capital does not work on the most powerful domestic markets, being concentrated mainly in the sphere of small business. In the context of realizing the doctrine of strategic partnership, this situation is not quite acceptable. It reflects caution in the behavior and attitude of Polish investors towards the Ukrainian economy, and their willingness not to invest in highly-valued and long-term-recovered investment projects on the Ukrainian market.

On the one hand, this may indicate underuse of Ukraine possibilities of effective cooperation with one of the most promising strategic partners in Europe, and on the other - indicates the absence of appropriate conditions in Ukraine for stable and confident work of Polish entrepreneurs who do not feel to be sufficiently protected here.

Experts point out that the main problems of Polish investors in the Ukrainian market are corruption, not transparent legislation, and the insolvency of the counterparties. Polish investors complain about unpredictable behavior of Ukrainian administration, corruption and inefficiency of the courts. Almost all of them are experiencing problems with export refunds. Often, the Ukrainian government sets an ultimatum to the Polish businessmen, namely offering VAT refunds in the case paying a certain amount of financial costs in the form of advance payment of future taxes. Polish companies also suffer from a low payment ability of their Ukrainian partners, banks in particular, which entails blocking implementation of the relevant financial transactions and leads to losses (Polish investors..., 2009). 
Besides the VAT debts, Polish businessmen are concerned about the dominance of bureaucracy in Ukraine, the state's inability to effectively protect their property rights, the difficulties of accounting and other (Business community...). In this regard, it is not rare to find the Polish press titles like: "You may lose investment during one day in Ukraine", and relevant publications cite numerous examples of troubles that representatives of Polish companies had in Ukraine, among them Magnus, Star-Print, Hator, Kredobank, Organika, Bioton and others (Pryadko). All this creates quite an unpleasant image among many Polish entrepreneurs about the specifics of the Ukrainian market, repelling them from investing in Ukraine.

The situation is complicated by contradictions in the current legislation of our country. In particular, analysts point out that the law on mineral resources is an article which says that the land lot of a license owner should be given by the state. And that is despite the fact that the land had long been privately owned by hundreds of different people. Effective legislation on subsoil use in Ukraine does not practically exist. Therefore, any officer can easily slow down the case (Khudytskyy, 2010). In this case, investing in major projects and strong industrial sites (or even the development of tourism and hotel network) is rather problematic. This is becoming an obstacle to the entry of the Polish capital into the key sectors of Ukrainian economy.

In particular, the Polish Ambassador to Ukraine Ya. Klyuchkovsky believes that our government should use the Polish experience in order to improve the competitiveness of the economy. According to him, it will attract into Ukraine not only large Polish, but Western investment: "economy is not only the production of money for the owners of large companies, it is primarily the competitiveness, and Polish experience could be useful for Ukraine" (The Ambassador things..., 2010). In particular, Poland could take part in the implementation of economic projects in which it has a positive experience and its own interests in terms of bilateral cooperation with Ukraine. First of all, according to the vice minister of the Ministry of Regional Development of Poland Krzysztof Hetman, it refers to the construction of quality roads and border crossing customs at the Ukrainian-Polish border, particularly those that will connect the least developed frontier territory of Ukraine with Poland (Khudytskyy, 2010).

Even in the crisis year of 2008 a positive trend of Polish investments coming to Ukraine was not interrupted, although a little fall of dynamics of the Polish capital investment into the Ukrainian economy was observed (Figure 2).

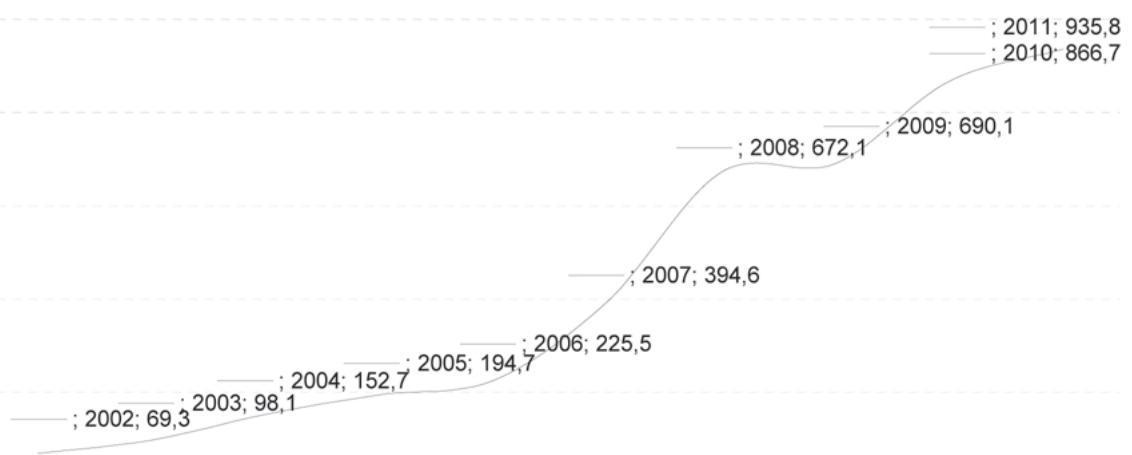

Figure 2. The dynamics of FDI from Poland to Ukraine, at the beginning of the year, mln US dollars Source: State Committee of Statistics and Ministry of economy of Ukraine. 
Exploring at this background the state and prospects of Ukrainian direct investment of capital into Poland, as already noted, priority attention is drawn to a significantly lower volume of activity of domestic investors on the Polish market than Polish entrepreneurs in Ukraine. This is caused by generally lower potential of the Ukrainian economy, and some subjective assumptions.

First of all, it should be noted that domestic industries, which accumulates the largest share of investment capital, face a number of difficulties. Firstly, it concerns the large energy consumption in Ukraine which is one of the highest in the world. As a result, the productivity of a metallurgist in the country is in 10 - 15 times lower than in the factories of Europe and out of 170 billion m3 of Russian gas that in 2010 was exported almost 35 billion $\mathrm{m} 3$ of this strategic resource was directed to Ukrainian economy (The country that doesn't need energetic independence...). It should be noted that the cost of energy resources for Ukraine is quite high in recent years. And experts predict that the "price of Russian gas for Ukraine in the third quarter of 2011 is projected at $\$ 350$ per 1 thousand $\mathrm{m} 3$, and in the fourth quarter, it could exceed $\$ 400$ per 1 thousand $\mathrm{m} 3$ ". It should be noted that the cost of energy resources to Ukraine in recent years is quite high. And this year experts predict that the "price of Russian gas for Ukraine in the third quarter of 2011 is projected at $\$ 350$ per 1 thousand $\mathrm{m} 3$, and in the fourth quarter, it could exceed $\$ 400$ per 1 thousand $\mathrm{m} 3$ " (The country that doesn't need energetic independence...).

Second, within the economic crisis that has hit Ukrainian economy hard enough, potential of foreign investment to domestic enterprises has significantly decreased, as reflected in the Ukrainian-Polish investment cooperation. And finally - the third reason, which limits the amount of direct investment from Ukraine abroad, including to Poland, is the political instability that causes major domestic entrepreneurs to abandon the strategic development of business models, focusing on the implementation of short-term projects. In this case, the investment capacity of their businesses on foreign markets is substantially limited.

National small businesses are not able to make active investments abroad, particularly in Poland, and, although it is their matches at present that are one of the most successful Polish investors on the Ukrainian market. This is due mainly to the specificity of Ukrainian small businesses, which, in contrast to Poland, so far have not gained sufficient financial strength and investment potential.

Currently, the most significant Ukrainian investment projects on the Polish market are: Warsaw Automobile Plant (investor - "Auto-ZAZ”), Metallurgical Plant "HutaChenstohova” (Guta-Czestochowa) (investor - "ISD”), ᄀ ship building plant “Stocznia Gdanska" (investor - "ISD”) and metal-trader "TsentrostalBydhosch” (Centrostal Bydgoszcz) (investor -"UMMC”).

\section{CONCLUSIONS}

Today Ukraine has not the best reputation among Polish entrepreneurs and partly because of ignoring the repeatedly declared investors' concerns by the authorities. Polish experts stress that the Ukrainian government, which, during the numerous meetings of intergovernmental commissions, economic summits, meetings of presidents and prime ministers, etc., undertook to resolve urgent issues of entrepreneurs from Poland and Ukraine in implementing investment projects unfortunately, was unable to meet its obligations. And it usually concerns not some exceptional problems of Polish investors in Ukraine or special relationship to them, but the general conditions of doing business, creating a favorable investment climate, economic stability and following the rules of the law (Butusov Yu. Jacek Piechota, 2011).

However, despite the presence of many of these problems, a common interest of Ukrainian and Polish investors and significant integration potential of economies of our countries, are leveling most of 
them, which is displayed in the constant growth of total amount of direct Polish investment into Ukrainian economy throughout the last decade.

\section{REFERENCES}

Borshchevskyy, V. (2009), Ukraine and Poland under the conditions of enlarged EU: economic optimization and global partnership / Борщевський В. Україна і Польща в умовах розширеного ЄС: економічна оптимізація та глобальне партнерство). - Львів : Аверс, 2009. - С. 82.

Butusov, Yu. (2011), Jacek Piechota: Ukraine doesn't have the best reputation among Polish businessmen / Бутусов Ю. Яцек Пєхота: «Україна має не найкращу репутацію в очах польських підприємців» // Дзеркало тижня. - 2011. - №5, 11лютого [Internet source]. - http://dt.ua/articles/75349.

Khudytskyy, V. (2010), Ukraine is no ready / Худицький В. Україна не готова. До створення сприятливого інвестиційного клімату руки не доходять// Дзеркало тижня. - 2010. - №38, 16 жовтня [Internet source]. http://dt.ua/articles/61225.

Pryadko, V. The problems of Polish firms in Ukraine / Прядко В. Проблеми польських фірм в Україні [Internet source]. - http://www2.polskieradio.pl/zagranica/ua/news/artykul91119.html.

Investment cooperation between Ukraine and the Republic of Poland (2010) [Internet resource]. - http://www.ukrexport.gov.ua/ukr/inf_spiv/pol/5119.html.

Polish investors on the Eastern markets and in Ukraine (Ukr.) (09.10.09) [Internet resource]. - http://www.ukrexport. gov.ua/ukr/inf_spiv/pol/2398.html.

Business community of Poland and Ukraine will unite theor efferts / Ділова спільнота Польщі та України об'єднають зусилля [Internet source]. - http://www.potencial.org.ua/view/news/dilova-spilnota-polshchi-ta-ukraini-obiednayut-zusillya.html.

The Ambassador thinks the investment climat of Ukraine has significantly decreased / Посол Польщів важає, що інвестиційний клімат в Україні помітно погіршився [Internet source]. - http://www.newsru.ua/finance/ 22mar2010/kluch.html.

The country that doesn't need energetic independence / Країна, якій не потрібна енергетична незалежність [Internet source]. - http://zaxid.net/article/84790/.

They say about increase in gas prices at Ministry of Energy / У Міненерго заговорили про подорожчання російського газу до \$ 400 [Internet source]. - http://gazeta.ua/articles/business/382342. 